Article

\title{
The Anti-Periodontitis Effects of Ethanol Extract Prepared Using Lactobacillus paracasei subsp. paracasei NTU 101
}

\author{
Te-Hua Liu ${ }^{1}$, Tsung-Yu Tsai ${ }^{2}$ and Tzu-Ming Pan ${ }^{1, *}$ \\ 1 Department of Biochemical Science \& Technology, National Taiwan University, Taipei 10617, Taiwan; \\ d04b22005@ntu.edu.tw \\ 2 Department of Food Science, Fu Jen Catholic University, New Taipei City 24205, Taiwan; \\ tytsai@mail.fju.edu.tw \\ * Correspondence: tmpan@ntu.edu.tw; Tel.: +886-2-3366-4519 (ext. 10)
}

Received: 19 March 2018; Accepted: 10 April 2018; Published: 12 April 2018

\begin{abstract}
Poor oral health and related diseases, including caries, periodontal disease, and oral cancer, are highly prevalent across the world, particularly in the elderly. This study aimed to investigate the anti-periodontitis activity of fermented skim milk produced using the promising probiotic Lactobacillus paracasei subsp. paracasei NTU 101 (NTU101FM). An initial analysis found that an ethanol extract of NTU101FM displayed anti-oxidative activities. Further investigation of pathogen growth inhibition zones, minimum inhibitory concentrations (MICs), and minimum bactericidal concentrations (MBCs) revealed that the NTU101FM ethanol extract also had anti-periodontal pathogen activities. In addition, the NTU101FM ethanol extract significantly decreased the release of pro-inflammatory cytokines induced by lipopolysaccharide (LPS) in RAW 264.7 macrophage cells. Finally, the NTU101FM ethanol extract was found to inhibit receptor activator of nuclear factor- $\kappa B$ ligand (RANKL)-induced osteoclast differentiation by reducing tartrate-resistant acid phosphatase (TRAP) activity and the number of TRAP-positive multinucleated osteoclasts. In summary, our study demonstrated that ethanol extract prepared from NTU101FM has potential use as an anti-periodontitis agent.
\end{abstract}

Keywords: Lactobacillus paracasei subsp. paracasei NTU 101; fermented skim milk; anti-periodontitis; anti-inflammation; osteoclast differentiation

\section{Introduction}

Oral disease is a wide-spread and global health concern that has many different causes and manifestations. In particular, periodontal disease, the major cause of tooth loss in adults, is caused by inflammatory processes that occur in gingival tissues in response to bacterial accumulation on the teeth. Chronic periodontitis is classified as slight, moderate, or severe periodontitis [1-3]. Recently, several studies have indicated that Porphyromonas gingivalis and Aggregatibacter actinomycetemcomitans are the main pathogens associated with periodontal disease [4-6]. These pathogens and associated factors, particularly the lipopolysaccharide (LPS) endotoxin found in their cell walls, are crucial mediators of the inflammatory processes that occur in gingival tissues. They induce their effects by enhancing the release of pro-inflammatory cytokines such as interleukin (IL)-1 $\beta$, IL- 6 , and tumor necrosis factor- $\alpha$ $(\mathrm{TNF}-\alpha)[7,8]$. There are also several studies that indicate that oxidative stress, caused by reactive oxygen species (ROS), is an important factor that also contributes to periodontitis. Additionally, antioxidants have been found to display inhibitory effects on periodontitis and alveolar bone loss (ABL) $[9,10]$. Such ABL is often caused by an imbalance between bone resorption and formation. This imbalance is linked to the activity of receptor activator of nuclear factor- $k B$ ligand (RANKL) and the release of various pro-inflammatory cytokines [11]. 
Further work has suggested that probiotics may offer additional scope for improving oral healthcare and have been shown to be effective for many oral diseases, including periodontitis [12]. This is likely because imbalances between probiotic and pathogenic bacteria can increase the risk of periodontal disease [12]. Lactobacillus acidophilus, L. casei, L. fermentum, L. plantarum, L. rhamnosus, and L. salivarius are all common probiotic species found in saliva. Importantly, some of these species have been shown to associate with improved outcomes in patients with periodontal disease. For example, L. gasseri and L. fermentum are both more abundant in healthy individuals than in patients with periodontal disease [13]. L. paracasei ssp. paracasei and L. rhamnosus have also been demonstrated to be highly antagonistic towards major oral pathogens, such as Streptococcus mutans and P. gingivalis [14]. Finally, some probiotics can ameliorate the symptoms of periodontal disease by regulating various pro- and anti-inflammatory factors that are secreted by endothelial cells. For example, Krasse et al. (2006) [15] showed that L. reuteri can inhibit the growth of pathogenic bacteria through the production of the bacteriocins, reuterin and reutericyclin. This allows it to compete with pathogenic bacteria for adsorption sites and inhibits the release of inflammatory factors, subsequently improving periodontal inflammation symptoms in the patient [16,17].

One potential probiotic that may have anti-pathogenic activity is L. paracasei subsp. paracasei NTU 101 (NTU 101), which was originally isolated from the feces of an aboriginal neonate in Taiwan [18]. The isolate possesses numerous biological functions; research has indicated that NTU 101 has significant antioxidant activity [19], and that fermented NTU 101 preparations exert an immunomodulatory effect, potentially by inhibiting the inflammatory response [20,21]. In addition, NTU 101 has been shown to have inhibitory effects on the growth rates of many bacteria and yeast species, with the notable exception of Staphylococcus aureus; both NTU 101 and NTU 101-fermented soy skim milk have been shown to exert anti-caries effects and a reduction in the incidence of tooth decay [22,23]. However, there have been few studies investigating whether similar lactic acid bacteria (LAB) fermentations have any anti-periodontitis activity.

To investigate this potential activity, we investigated the anti-periodontitis activity of NTU 101-fermented skim milk (NTU101FM). Our data strongly suggest that ethanol extracts prepared from NTU101FM have potential use as anti-periodontitis agents, which can be used to improve outcomes for patients.

\section{Materials and Methods}

\subsection{Materials}

P. gingivalis BCRC 14417, A. actinomycetemcomitans BCRC 80375, and RAW 264.7 cells were purchased from the Bioresource Collection and Research Center (BCRC, Hsinchu, Taiwan). Dimethyl sulfoxide (DMSO), 3-(4,5-dimethylthiazol-2-yl)-2,5-diphenyltetrazolium bromide (MTT), L-glutamine, LPS, and receptor activator of nuclear factor- $k B$ ligand (RANKL) were all purchased from Sigma-Aldrich Corp. (St. Louis, MO, USA). Brain heart infusion agar, Mueller-Hinton agar, and tryptic soy broth were purchased from BD Co. (Franklin Lakes, NJ, USA). Fetal bovine serum (FBS) and Dulbecco's modified Eagle's medium (DMEM) were purchased from HyClone Laboratories (Logan, UT, USA). A tartrate-resistant acid phosphatase (TRAP) \& alkaline phosphatase (ALP) Double-stain Kit were purchased from Takara Bio Inc. (Kusatsu, Shiga, Japan) and pro-inflammatory cytokine assay kits (IL-1 $\beta$, IL-6, IL-17, and TNF- $\alpha$ ) were purchased from BioLegend (San Diego, CA, USA).

\subsection{Fermented Skim Milk with NTU 101 and Extraction}

For the fermentation, 25\% $(w / v)$ skim milk (Anchor, Auckland, New Zealand) was warmed in a water bath at $95{ }^{\circ} \mathrm{C}$ for $1 \mathrm{~h}$. The milk was then allowed to cool to $37^{\circ} \mathrm{C}$ and inoculated with a $1 \%$ $(v / v)$ suspension of NTU 101. It was then incubated at $37^{\circ} \mathrm{C}$ for 2 days before being freeze-dried using a SDF-25 freeze dryer (Chang Jung Business Co., Feng-Jen, Taiwan). Material was then extracted from the freeze-dried NTU 101-fermented skim milk (NTU101FM) powders using 95\% ethanol or water by 
shaking in a rotary shaker at $180 \mathrm{rpm}$ and $37^{\circ} \mathrm{C}$ for $1 \mathrm{~h}$. The extracts were then centrifuged at $4{ }^{\circ} \mathrm{C}$ and $10,000 \times g$ for $30 \mathrm{~min}$ to obtain the supernatant. The supernatants were then dried in vacuo and stored at $-20{ }^{\circ} \mathrm{C}$ until use.

\subsection{Evaluation of the Anti-Oxidant Properties of NTU101FM}

Several methods were used to assess the anti-oxidant properties of NTU101FM. First, the 2,2-diphenyl-1-picrylhydrazyl (DPPH)-eliminating activity was measured using $100 \mu \mathrm{L}$ of extracts of NTU101FM added to $500 \mu \mathrm{L}$ of $0.1 \mathrm{mM}$ DPPH solution and mixed. After incubation at room temperature (approximately $25^{\circ} \mathrm{C}$ ) for $30 \mathrm{~min}$ in the dark, the absorbance at $517 \mathrm{~nm}$ was measured for each mixture [24]. The reducing power of NTU101FM was assessed by adding $100 \mu \mathrm{L}$ of each extract to $100 \mu \mathrm{L}$ of $1 \% \mathrm{~K}_{3} \mathrm{Fe}(\mathrm{CN})_{6}$ and $100 \mu \mathrm{L}$ of $0.2 \mathrm{M}$ phosphate-buffered saline (PBS). After incubation at $50{ }^{\circ} \mathrm{C}$ for $20 \mathrm{~min}, 500 \mu \mathrm{L} \mathrm{10 \%}$ trichloroacetic acid (TCA) solution was added and the mixture was centrifuged at $4{ }^{\circ} \mathrm{C}$ and $3500 \times g$ for $10 \mathrm{~min}$ to obtain the supernatant. Double-distilled water and $0.1 \% \mathrm{FeCl}_{3}(w / v)$ were added to the supernatant at a ratio of 1:1:1. The absorbance at $700 \mathrm{~nm}$ of each mixture was then measured [25]. Finally, the $\mathrm{Fe}^{2+}$-chelating activity was measured using a previously outlined method [26].

\subsection{Anti-Microbial Activity of NTU101FM Ethanol Extract}

To establish the anti-microbial activity of NTU101FM, agar diffusion assays similar to previous studies were performed, with slight modifications [27,28]. Briefly, the assays utilized $1 \times 10^{9}$ colony-forming units $(\mathrm{CFU}) / \mathrm{mL}$ of each indicator bacterial species (P. gingivalis and A. actinomycetemcomitans) that were incubated using the same volumes of agar. The surfaces of the agar plates were swabbed several times with bacteria to ensure an even distribution of each indicator species. Next, a 7-mm diameter hollow tube was used to prepare four wells on each plate, into which $50 \mu \mathrm{L}$ of various concentrations (25 to $200 \mathrm{mg} / \mathrm{mL}$ ) of NTU101FM ethanol extract were added within a 10 -min period. The plates were then incubated at $37^{\circ} \mathrm{C}$ in an anaerobic incubator for 2 or 4 days. The diameter of the inhibition zone around each well was then measured.

To establish the lowest concentration at which there was inhibition of bacterial growth, minimum inhibitory concentrations (MICs) were measured according to previous studies, with some modifications [28]. Briefly, $1 \times 10^{9} \mathrm{CFU} / \mathrm{mL}$ indicator bacteria (P. gingivalis or A. actinomycetemcomitans) were incubated with different concentrations of NTU101FM ethanol extract. After incubation, the MICs were determined by visual inspection and by noting the concentrations at which there was no visible growth. Finally, the minimum bactericidal concentrations (MBCs) were measured with previously described method [29].

\subsection{Cell Culture and Cell Viability}

RAW 264.7 mouse cells were maintained in DMEM medium with $10 \%$ FBS at $37{ }^{\circ} \mathrm{C}, 95 \%$ humidity, and $5 \% \mathrm{CO}_{2}$. For passage, cells were dislodged from the dish substrate using a cell scraper, aspirated, and added to new dishes when required. The culture medium was replaced every 2-3 days. To determine cell viability, RAW 264.7 cells were seeded at $1 \times 10^{4}$ cells $/$ well on a 24 -well plate. After $24 \mathrm{~h}$, the cells were incubated with NTU101FM ethanol extract for a further $24 \mathrm{~h}$. Cell viability was then assessed using MTT assays and calculated using the following equation: cell viability (\% of control $)=\left(\mathrm{OD}_{\text {sample }} / \mathrm{OD}_{\text {control }}\right) \times 100 \%$, where OD is optical density at $595 \mathrm{~nm}$.

\subsection{Measurement of Nitric Oxide (NO) Production Levels}

NO content was measured as previously described [30]. Briefly, RAW 264.7 cells were seeded at $1 \times 10^{4}$ cells/well on a 24 -well plate and left for $48 \mathrm{~h}$. The cells were then incubated with NTU101FM ethanol extract for a further $24 \mathrm{~h}$. To determine the NO levels, $50 \mu \mathrm{L}$ aliquots of the cultured supernatants or standard were mixed with $50 \mu \mathrm{L}$ sulfanilamide solution (1\% sulfanilamide in 
$5 \%$ phosphoric acid) and $50 \mu \mathrm{L} 0.1 \% \mathrm{~N}$-(1-naphthyl) ethylenediamine dihydrochloride (NED) solution. The mixture was then incubated at room temperature for $10 \mathrm{~min}$ in the dark and the absorbance of each mixture was measured.

\subsection{Measurement of Pro-Inflammatory Cytokine (IL-1 $\beta, I L-6, I L-17$, and TNF- $\alpha$ ) Levels}

The levels of IL-1 $\beta$ (No. 432605), IL-6 (No. 431305), IL-17 (No. 432505), and TNF- $\alpha$ (No. 430905) in the cultured supernatant were tested using enzyme-linked immunosorbent assay (ELISA) kits (BioLegend, San Diego, CA, USA) according to the manufacturer-provided protocols.

\subsection{Osteoclast Differentiation, Tartrate-Resistant Acid Phosphatase (TRAP) Staining, and TRAP Activity}

To assess the effects of NTU101FM ethanol extract on osteoclast differentiation, $1 \times 10^{4}$ cells/well RAW 264.7 cells were plated onto 24-well plates. After $24 \mathrm{~h}$, the medium was substituted and the cells were co-cultured for a further 4 days in DMEM complemented with 10\% FBS, $100 \mathrm{ng} / \mathrm{mL}$ RANKL, and different concentrations ( 25 to $500 \mu \mathrm{g} / \mathrm{mL}$ ) of NTU101FM ethanol extract.

On the fourth day of differentiation, the cultured supernatants were removed and discarded. The cells were washed once with PBS, and $250 \mu \mathrm{L}$ of fixation solution (citrate buffer containing $60 \%$ acetone and $10 \%$ methanol) was added. The cells were then left at room temperature for 5 min. Finally, cells were stained using a TRACP \& ALP Double-stain Kit (Cat. MK300; Takara Bio Inc., Kusatsu, Shiga, Japan). Images of TRAP-positive cells were captured using a TS100 inverted microscope with a camera (Nikon, Tokyo, Japan). The TRAP activity of these cells under different treatment options were tested by ELISA.

\subsection{Assessment of Bone Resorptive Area by Pit Formation Assay}

To assess bone resorption, a pit formation assay was used with culturing methods similar to those for osteoclast differentiation, although $1 \times 10^{4}$ RAW 264.7 cells/well were plated onto Corning Osteo Assay Surface Multiwell plates (Corning Inc., Corning, NY, USA). After $24 \mathrm{~h}$, the cells were treated with RANKL (100 ng/mL) and NTU101FM ethanol extract for 4 days. The cells were then removed using $1 \mathrm{~N} \mathrm{NaOH}$ for $15 \mathrm{~min}$, and the resorbed areas were observed under a TS100 inverted microscope (Nikon, Tokyo, Japan) and analyzed using Image J [31].

\subsection{Statistical Analysis}

All data are represented as the mean \pm standard deviation (SD) from three independent experiments. A Duncan's multiple range test with a post hoc analysis was used for statistical testing using SPSS software (version 21, IBM Software, Armonk, NY, USA). The threshold for statistical significance was set as $p<0.05$.

\section{Results and Discussion}

\subsection{The Anti-Oxidative Activities of NTU101FM}

Chapple and Matthews (2007) [9] previously reported that oxidative stress is a key factor that contributes to periodontitis, affecting many interactions between the host and pathogen. When the redox-state of a host is unbalanced, periodontal disease can be exacerbated. In addition, increasing the activities or abundances of anti-oxidative enzymes, or otherwise decreasing oxidative stress in the host, can improve periodontal status [10]. In this study, we assessed the anti-oxidative properties of NTU101FM using DPPH elimination, reducing power, and $\mathrm{Fe}^{2+}$-chelating assays. As shown in Table 1, the DPPH eliminating activities of water and ethanol NTU101FM extract at $20 \mathrm{mg} / \mathrm{mL}$ were significantly higher than that of unfermented skim milk by $14.47 \%$ and $15.40 \%$, respectively $(p<0.05)$. These activities also demonstrated a dose-dependent effect. In addition, both unfermented and NTU101FM extracts increased the total reducing activity in a dose-dependent manner, although the ethanol extract was more effective. Finally, the $\mathrm{Fe}^{2+}$-chelating activity was significantly enhanced by 
NTU101FM $(p<0.05$, data not shown). These results demonstrated that skim milk fermented with NTU 101 possessed anti-oxidative activities.

Table 1. The 1,1-diphenyl-2-picrylhydrazyl (DPPH) eliminating and reducing power activities of unfermented skim milk or NTU101FM extracts.

\begin{tabular}{|c|c|c|c|c|c|c|c|c|}
\hline \multirow{2}{*}{$\begin{array}{l}\text { Concentration } \\
(\mathrm{mg} / \mathrm{mL})\end{array}$} & \multicolumn{4}{|c|}{ DPPH Eliminating Effect (\%) } & \multicolumn{4}{|c|}{ Reducing Power $\left(\mathrm{OD}_{700}\right)$} \\
\hline & UF EE & UF WE & NTU 101 EE & NTU 101 WE & UF EE & UF WE & NTU $101 \mathrm{EE}$ & NTU 101 WE \\
\hline 20.0 & $50.94 \pm 2.06^{\mathrm{Ac}}$ & $45.11 \pm 4.24^{\mathrm{Ac}}$ & $66.34 \pm 3.57^{\mathrm{Aa}}$ & $59.58 \pm 4.17^{\mathrm{Ab}}$ & $0.451 \pm 0.03^{\mathrm{Ac}}$ & $0.215 \pm 0.01 \mathrm{Ad}$ & $0.604 \pm 0.02 \mathrm{Aa}$ & $0.350 \pm 0.01 \mathrm{Ab}$ \\
\hline 10.0 & $42.55 \pm 1.51^{\mathrm{Bc}}$ & $37.36 \pm 1.03^{\mathrm{Bd}}$ & $59.66 \pm 1.64 \mathrm{Ba}$ & $54.15 \pm 1.55^{\mathrm{Bb}}$ & $0.389 \pm 0.00^{\mathrm{Bb}}$ & $0.207 \pm 0.00^{\mathrm{ABd}}$ & $0.507 \pm 0.02 \mathrm{Ba}$ & $0.288 \pm 0.01 \mathrm{Bc}$ \\
\hline 1.0 & $27.11 \pm 2.49^{\mathrm{Dc}}$ & N.D. & $45.36 \pm 1.98^{\mathrm{Da}}$ & $35.24 \pm 1.01 \mathrm{Db}$ & $0.276 \pm 0.00 \mathrm{Da}$ & $0.121 \pm 0.01 \mathrm{Cb}$ & $0.275 \pm 0.01 \mathrm{Da}$ & $0.251 \pm 0.04 \mathrm{CDa}$ \\
\hline 0.1 & $16.06 \pm 1.54 \mathrm{Ec}$ & N.D. & $40.95 \pm 2.09 \mathrm{Ea}$ & $28.11 \pm 2.21 \mathrm{~Eb}$ & $0.207 \pm 0.00^{\mathrm{Eb}}$ & $0.070 \pm 0.02 \mathrm{Dc}$ & $0.236 \pm 0.01 \mathrm{Ea}$ & $0.225 \pm 0.01^{\mathrm{Dab}}$ \\
\hline
\end{tabular}

Data are presented as mean $\pm \mathrm{SD}(n=3)$. Values with different uppercase letters were significantly different in column and values with different lowercase letters were significantly different in row $(p<0.05)$. DPPH: $0.1 \mathrm{mM}$. UF EE: ethanol extract of unfermented skim milk; UF WE: water extract of unfermented skim milk; NTU $101 \mathrm{EE}$ : ethanol extract of L. paracasei subsp. paracasei NTU 101-fermented skim milk; NTU 101 WE: water extract of L. paracasei subsp. paracasei NTU 101-fermented skim milk; N.D.: non-detected.

\subsection{The Anti-Microbial Activities of NTU101FM}

Based on the results of the anti-oxidation assays, we hypothesized that the NTU101FM ethanol extract would be more effective than the water extract. Therefore, NTU101FM ethanol extract was used for subsequent assays to assess the inhibitory ability of NTU 101 on periodontal pathogens. Several factors have been found to promote periodontal disease, including eating habits, poor oral hygiene, and faulty dental restorations. However, the main factor is dental plaque formed by various oral pathogens $[32,33]$. Therefore, inhibiting the growth of periodontal pathogens would effectively prevent or improve the periodontal status. The degree of growth inhibition against $P$. gingivalis and A. actinomycetemcomitans by NTU101FM ethanol extract are shown in Table 2. These results showed that both $P$. gingivalis and A. actinomycetemcomitans were inhibited by treatment with $200 \mathrm{mg} / \mathrm{mL}$ NTU101FM ethanol extract. The diameters of the growth inhibition zones for $P$. gingivalis and A. actinomycetemcomitans were $16.50 \pm 0.20$ and $22.75 \pm 0.35 \mathrm{~mm}$, respectively. In particular, treatment with 25 to $200 \mathrm{mg} / \mathrm{mL}$ of NTU101FM ethanol extract still led to a noticeable inhibition zone in A. actinomycetemcomitans. MIC and MBC comparisons are shown in Table 3. The MICs and MBCs of the NTU101FM ethanol extract were both $30 \mathrm{mg} / \mathrm{mL}$ for $P$. gingivalis, and were 1.0 and $2.5 \mathrm{mg} / \mathrm{mL}$, respectively, for A. actinomycetemcomitans.

Several prior studies have reported that certain Lactobacillus spp. can produce bacteriocins. These can often feature better anti-microbial effects than traditional antibiotics [34]. Furthermore, Sookkhee et al. (2001) [14] found that enhancing the abundance of oral L. paracasei ssp. paracasei (D6, D4, N14) or L. rhamnosus could decrease the number of periodontal pathogens. In addition, bacteriocins produced by L. paracasei HL32 can destroy the cytomembranes of P. gingivalis, decreasing its abundance [35]. Previously, NTU 101 has been shown to possess anti-microbial activity against a wide variety of pathogens, including Gram-negative bacteria [22]. We therefore concluded that our NTU101FM ethanol extract contained the specific anti-microbial ingredient(s) that acts against periodontal pathogens.

Table 2. Inhibition zone of NTU101FM ethanol extract against periodontal pathogens.

\begin{tabular}{ccc}
\hline \multirow{2}{*}{ Concentrations (mg/mL) } & \multicolumn{2}{c}{ Inhibition Zone (Diameter, mm) ${ }^{\mathbf{a}, \mathbf{b}}$} \\
\cline { 2 - 3 } & P. gingivalis BCRC 14417 & A. actinomycetemcomitans BCRC 14405 \\
\hline 200 & $16.50 \pm 0.20$ & $22.75 \pm 0.35$ \\
100 & - & $19.50 \pm 1.41$ \\
50 & - & $18.50 \pm 0.71$ \\
25 & - & $11.75 \pm 1.06$
\end{tabular}

a Inhibition zone does not include the disc diameter $(7 \mathrm{~mm}){ }^{\mathrm{b}}$ - No inhibition zone. The cultures, containing approximately $1 \times 10^{9}$ colony-forming unit $(\mathrm{CFU}) / \mathrm{mL}$ of indicator bacteria, were inoculated on the agar plate. NTU101FM, NTU 101-fermented skim milk. 
Table 3. Minimum inhibitory concentration (MIC) and minimum bactericidal concentration (MBC) of NTU101FM ethanol extract against periodontal pathogens.

\begin{tabular}{ccc}
\hline Periodontal Pathogens & MIC $(\mathbf{m g} / \mathbf{m L})$ & MBC $(\mathbf{m g} / \mathbf{m L})$ \\
\hline P. gingivalis BCRC 14417 & 30.00 & 30.00 \\
A. actinomycetemcomitans BCRC 14405 & 1.00 & 2.50 \\
\hline
\end{tabular}

\subsection{RAW 264.7 Cell Viability after Treatment with NTU101FM Ethanol Extract}

To find a safe yet effective concentration of NTU101FM ethanol extract, we measured the cell viability of RAW 264.7 cells after treatment with various concentrations of the extract. As shown in Figure 1, there was no cytotoxicity observed in RAW 264.7 cells between 50 and $500 \mu \mathrm{g} / \mathrm{mL}$ NTU101FM ethanol extract. We therefore decided to use concentrations below $500 \mathrm{mg} / \mathrm{mL}$ in subsequent experiments.

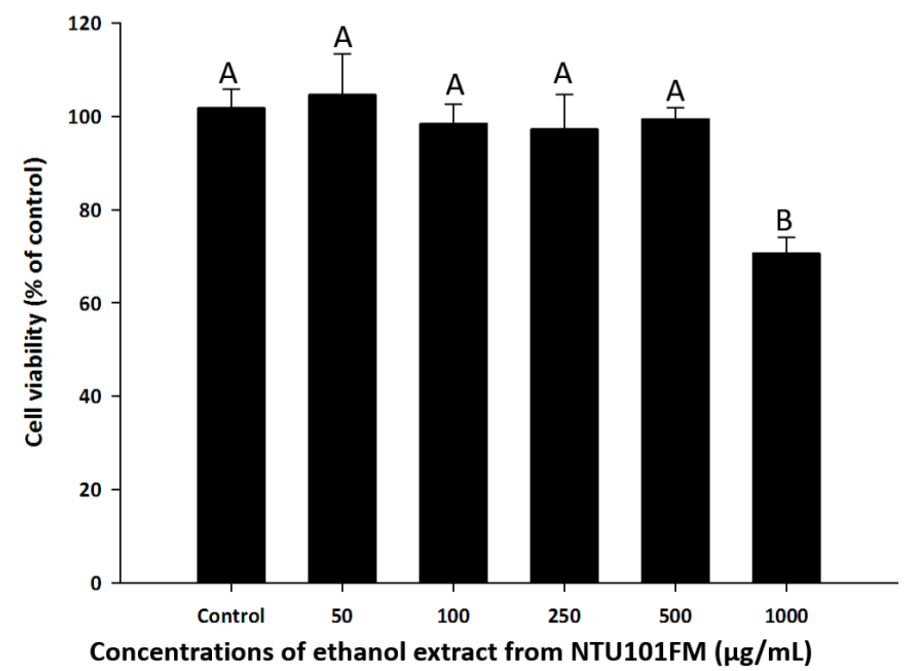

Figure 1. Effects of NTU101FM ethanol extract on cell viability of RAW 264.7 cell. Cells were treated with various concentrations of NTU101FM ethanol extract (50 to $1000 \mu \mathrm{g} / \mathrm{mL}$ ) for $24 \mathrm{~h}$. Cell viability was measured by MTT assay and represented as percent of control cell viability. The data are presented as means $\pm \mathrm{SD}(n=3)$. Values with different uppercase letters were significant by Duncan's multiple range tests $(p<0.05)$. NTU101FM, NTU 101-fermented skim milk; MTT, 3-(4,5-dimethylthiazol-2-yl)-2,5-diphenyltetrazolium bromide.

\subsection{The Anti-Inflammatory Activities of NTU101FM Ethanol Extract on RAW 264.7 Cells}

As previously described, periodontitis is a chronic inflammatory disease. In mediating their probiotic effects against periodontitis, Lactobacillus spp. may either regulate the immune response or reduce inflammation [36]. Even though the anti-inflammatory mechanisms remain unclear, Cotter et al. (2005) [37] showed that these effects may associate with polysaccharides, peptidoglycans, or bacteriocins secreted by Lactobacillus spp. In addition, when the levels of NO are too high, the peroxidation of free radicals can lead to negative cytotoxicity or inflammatory reactions [38]. However, NO is not typically produced by non-activated macrophages and is only secreted after activation by certain cytokines (such as IL-1 and TNF- $\alpha$ ) or LPS [39]. Therefore, LPS-induced inflammation in a RAW 264.7 cell model can be used to assess the levels of inflammation and the impact of treatments on inflammatory processes. Using this LPS-induced inflammation model, we measured the effects of NTU101FM ethanol extract on NO, IL-1 $\beta$, IL-6, TNF- $\alpha$, and IL-17 levels. We initially confirmed that RAW 264.7 cells do not produce pro-inflammatory cytokines after treatment with 25 to $500 \mathrm{mg} / \mathrm{mL}$ of NTU101FM ethanol extract when compared to the control group (data not shown). After RAW 264.7 cells were co-cultured with $100 \mathrm{ng} / \mathrm{mL}$ LPS for $24 \mathrm{~h}$, NO production significantly increased 
27.51-fold relative to control group ( $p<0.05$; Figure 2A). However, treatment with 100 to $500 \mu \mathrm{g} / \mathrm{mL}$ NTU101FM ethanol extract successfully reduced NO levels in the LPS-induced RAW 264.7 macrophage model (Figure 2A). In addition, the levels of TNF- $\alpha$, IL-6, IL-1 $\beta$, and IL-17 in the cellular supernatants of the LPS groups also significantly increased to $460.45 \pm 0.56 \mathrm{pg} / \mathrm{mL}(111.18 \%), 854.25 \pm 5.96 \mathrm{pg} / \mathrm{mL}$ $(78.66 \%), 145.50 \pm 9.82 \mathrm{pg} / \mathrm{mL}(210.68 \%)$, and $202.96 \pm 7.70 \mathrm{pg} / \mathrm{mL}(33.44 \%)$, respectively $(p<0.05 ;$ Figure 2B-E). Treatment with NTU101FM ethanol extract (100 to $500 \mu \mathrm{g} / \mathrm{mL}$ ) significantly reduced the levels of TNF- $\alpha$ (by $14.15 \%$ to $48.76 \%$ ), IL-6 (by $6.87 \%$ to $54.53 \%$ ), IL-1 $\beta$ (by 39.12\% to 204.18\%), and IL-17 (by $5.60 \%$ to $22.12 \%$ ), when compared to the LPS-only groups $(p<0.05)$. These results indicated that treatment with NTU101FM ethanol extract regulates the anti-inflammatory responses by reducing the levels of pro-inflammatory cytokines induced by LPS.

A
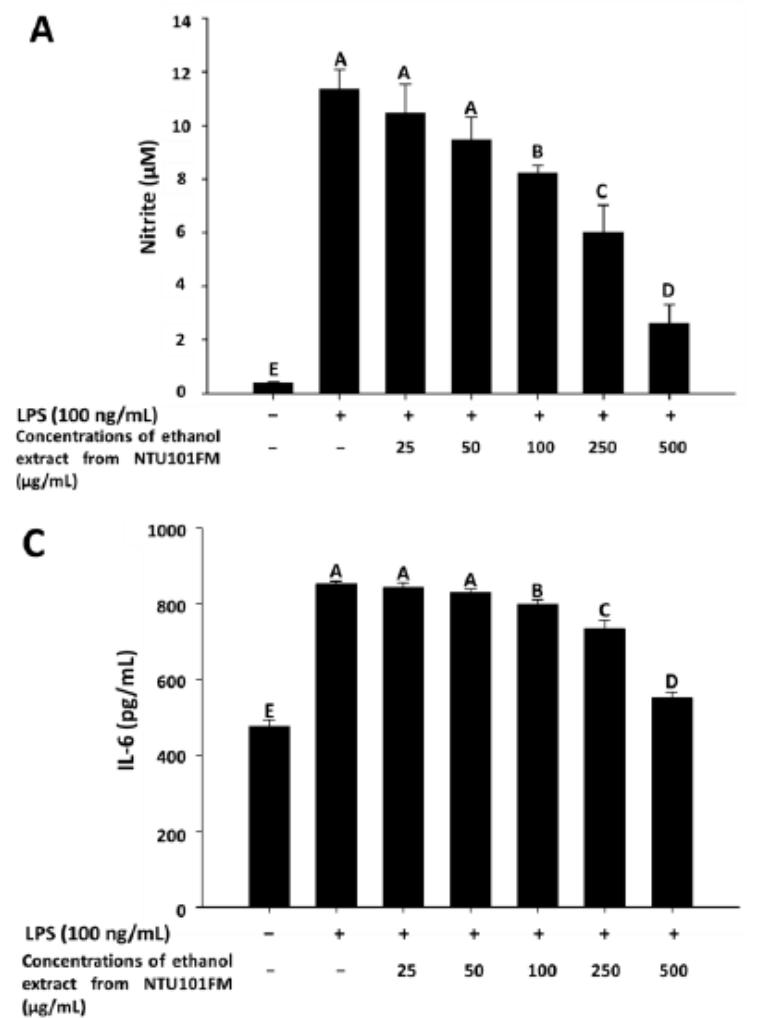
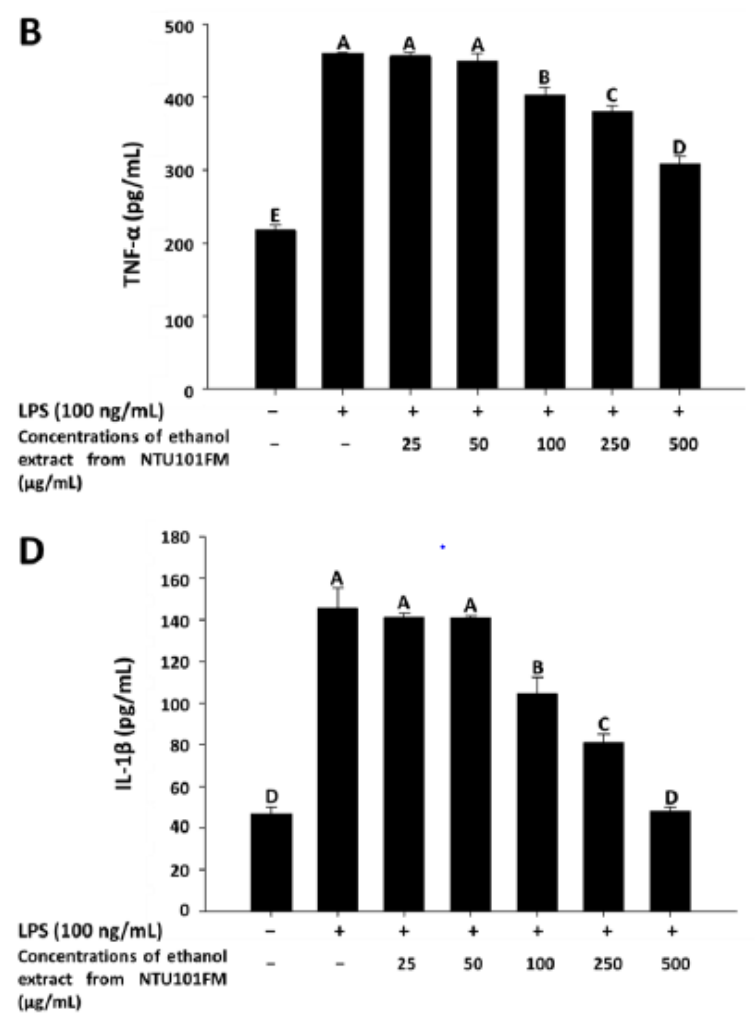

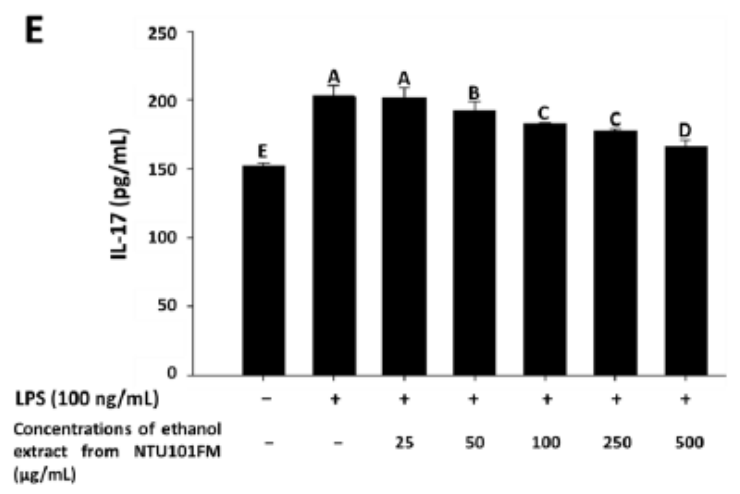

Figure 2. Effects of NTU101FM ethanol extract on: (A) NO; (B) TNF- $\alpha$; (C) IL-6; (D) IL-1 $\beta$; and (E) IL-17 of LPS-induced inflammation RAW 264.7 cell. Cells were treated with various concentrations of NTU101FM ethanol extract $(25$ to $500 \mu \mathrm{g} / \mathrm{mL}$ ) for $24 \mathrm{~h}$. The data are presented as means $\pm \operatorname{SD}(n=3)$. Values with different uppercase letters were significant by Duncan's multiple range tests $(p<0.05)$. NTU101FM, NTU 101-fermented skim milk; NO, nitric oxide; TNF- $\alpha$, tumor necrosis factor- $\alpha$; IL-6, interleukin-6; IL-1 $\beta$, interleukin-1 $\beta$; IL-17, interleukin-17; LPS, lipopolysaccharide. 


\subsection{The Inhibitory Effects of NTU101FM Ethanol Extract on RANKL-Induced Osteoclastogenesis}

There is increasing evidence that alveolar bone loss (ABL) is an important indicator of periodontitis [40]. ABL depends on a balance between bone resorption and bone formation. Osteoclasts are large, multinucleated cells that originate from a macrophage lineage and induce bone resorption. This process is stimulated by RANKL and is induced into an overactive state by certain inflammatory cytokines, such as TNF- $\alpha$, IL-1, and IL-6 [41-43]. Previously, Ciucci et al. (2015) [44] reported that IL-17 and TNF- $\alpha$ were also regulators of osteoclastogenesis, either directly or indirectly. RANKL is an important protein that regulates osteoclast differentiation and function. Inhibiting osteoclastogenesis by reducing inflammation and osteoclast differentiation via RANKL is considered a possible strategy for preventing and ameliorating periodontitis [43]. To address whether NTU 101 could affect osteoclastogenesis, we first examined osteoclast differentiation using TRAP staining (Figure 3A). This showed that NTU101FM ethanol extract from concentrations of 100 to $500 \mu \mathrm{g} / \mathrm{mL}$ could suppress RANKL-induced osteoclast differentiation in RAW 264.7 cells. We also quantified the number of TRAP-positive multinucleated osteoclasts (Figure 3B), finding that the number of TRAP-positive multinucleated osteoclasts decreased after treatment with NTU101FM ethanol extract from 100 to $500 \mu \mathrm{g} / \mathrm{mL}(p<0.05)$. Compared to the RANKL-induced group treated only with $100 \mathrm{ng} / \mathrm{mL}$ RANKL, the NTU101FM ethanol extract significantly reduced the number of TRAP-positive multinucleated osteoclasts by $27.22 \%$ to $55.13 \%$ $(p<0.05)$. We next assessed TRAP activity in RAW 264.7 cells cultured with various doses of NTU101FM ethanol extract in the presence of RANKL for four days (Figure 3C). This revealed that the TRAP activities of differentiated RAW 264.7 cells were similar to the number of TRAP-positive multinucleated osteoclasts. However, NTU101FM ethanol extract (100 to $500 \mu \mathrm{g} / \mathrm{mL}$ ) decreased TRAP activity by $30.99 \%$ to $49.07 \%$ ( $p<0.05)$. These findings suggest that NTU101FM ethanol extract may reduce bone resorption by inhibiting the RANKL-induced osteoclast differentiation.
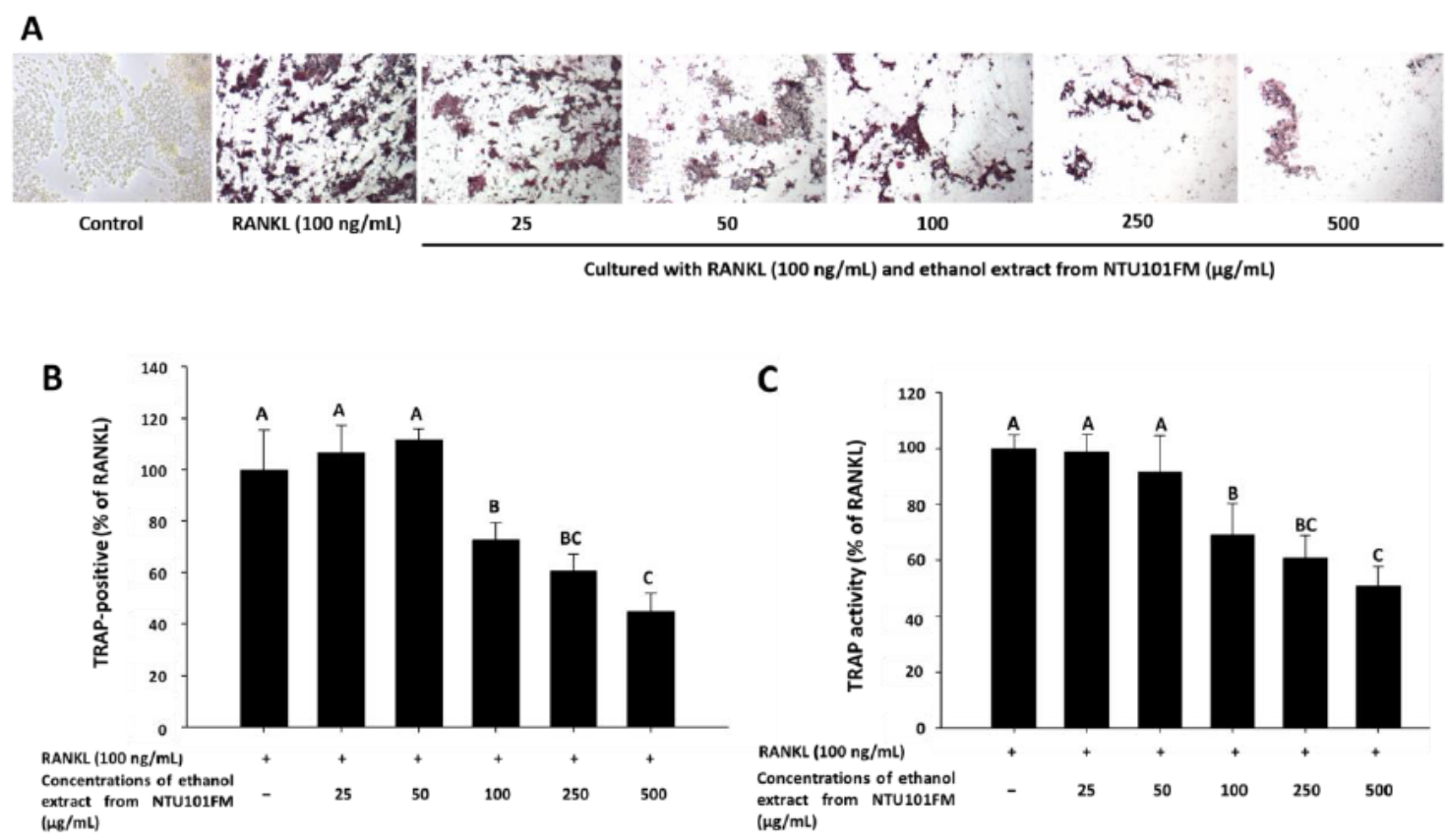

Figure 3. Effect of NTU101FM ethanol extract on RANKL-induced osteoclast differentiation: (A) photograph of TRAP-stained osteoclasts; (B) number of TRAP-positive multinucleated osteoclasts; and (C) TRAP activity. The RAW 264.7 cells were cultured with the indicated dose of NTU101FM ethanol extract (25 to $500 \mu \mathrm{g} / \mathrm{mL})$ in the presence of RANKL $(100 \mathrm{ng} / \mathrm{mL})$ for four days. The data are presented as means $\pm \mathrm{SD}$ $(n=3)$. Values with different uppercase letters were significant by Duncan's multiple range tests $(p<0.05)$. NTU101FM, NTU 101-fermented skim milk; RANKL, receptor activator of nuclear factor kappa- $\beta$ ligand; TRAP, tartrate-resistant acid phosphatase. 


\subsection{The Inhibitory Effects of NTU101FM Ethanol Extract on Bone Resorption}

Finally, we used a Corning Osteo Assay Surface system to measure the extent of bone resorption stimulated by RANKL (representative images are shown in Figure 4A). We observed a significant increase in the areas of bone resorption when RAW 264.7 cells were induced by RANKL for four days. However, after treatment with 100, 250, and $500 \mu \mathrm{g} / \mathrm{mL}$ NTU101FM ethanol extract, these areas of bone resorption were reduced by $15.85 \%, 22.67 \%$, and $63.30 \%$, respectively ( $p<0.05$; Figure $4 \mathrm{~B})$. This suggests that NTU101FM ethanol extract has an inhibitory effect on RANKL-induced bone resorption.

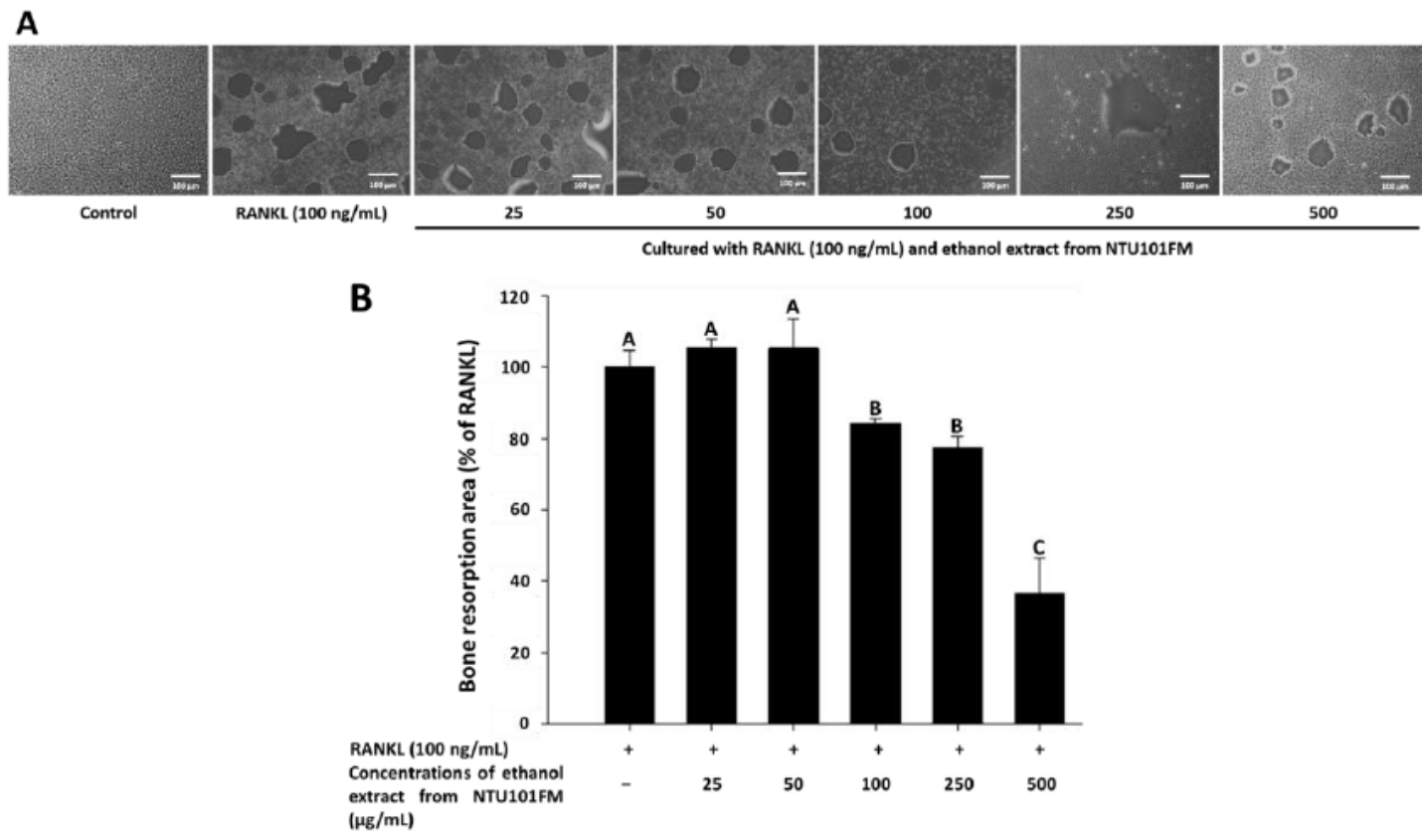

Figure 4. Effect of NTU101FM ethanol extract on RANKL-induced bone resorption: (A) photograph; and (B) the area in osteoclast. The RAW 264.7 cells were cultured with the indicated dose of NTU101FM ethanol extract ( 25 to $500 \mu \mathrm{g} / \mathrm{mL}$ ) in the presence of RANKL ( $100 \mathrm{ng} / \mathrm{mL}$ ) for four days. The data are presented as means $\pm \mathrm{SD}(n=3)$. Values with different uppercase letters were significant by Duncan's multiple range tests $(p<0.05)$. NTU101FM, NTU 101-fermented skim milk; RANKL, receptor activator of nuclear factor kappa- $\beta$ ligand.

\section{Conclusions}

Our data have revealed that an NTU101FM ethanol extract displayed significant anti-oxidative activities when assessed by DPPH elimination, reducing power, and $\mathrm{Fe}^{2+}$-chelating assays. Furthermore, NTU101FM ethanol extract could decrease the growth of both $P$. gingivalis and A. actinomycetemcomitans, pathogens majorly associated with periodontitis. Our study also demonstrated that NTU101FM ethanol extract affected LPS-induced inflammatory responses and RANKL-induced osteoclast differentiation in RAW 264.7 cells. Finally, we have demonstrated that NTU101FM ethanol extract inhibited RANKL-induced osteoclast differentiation by reduced TRAP activity and the total number of TRAP-positive multinucleated osteoclasts. NTU101FM ethanol extract also decreased the levels of RANKL-induced bone resorption. A summary of the proposed mechanism is shown in Figure 5. Our study is the first study to examine the potential role of an NTU101FM ethanol extract in combating periodontal disease. Our results strongly suggest that such an extract has the potential to act as a therapeutic agent for the prevention and treatment of periodontitis. However, the study was limited in that it used an in vitro model. Experiments using an LPS-induced periodontal disease animal model are currently being performed. It will confirm if our conclusions can be replicated in vivo. Such confirmation 
would suggest that an ethanol extract prepared using NTU 101 fermentation would have therapeutic applications that may improve the outcomes for patients with periodontal disease.

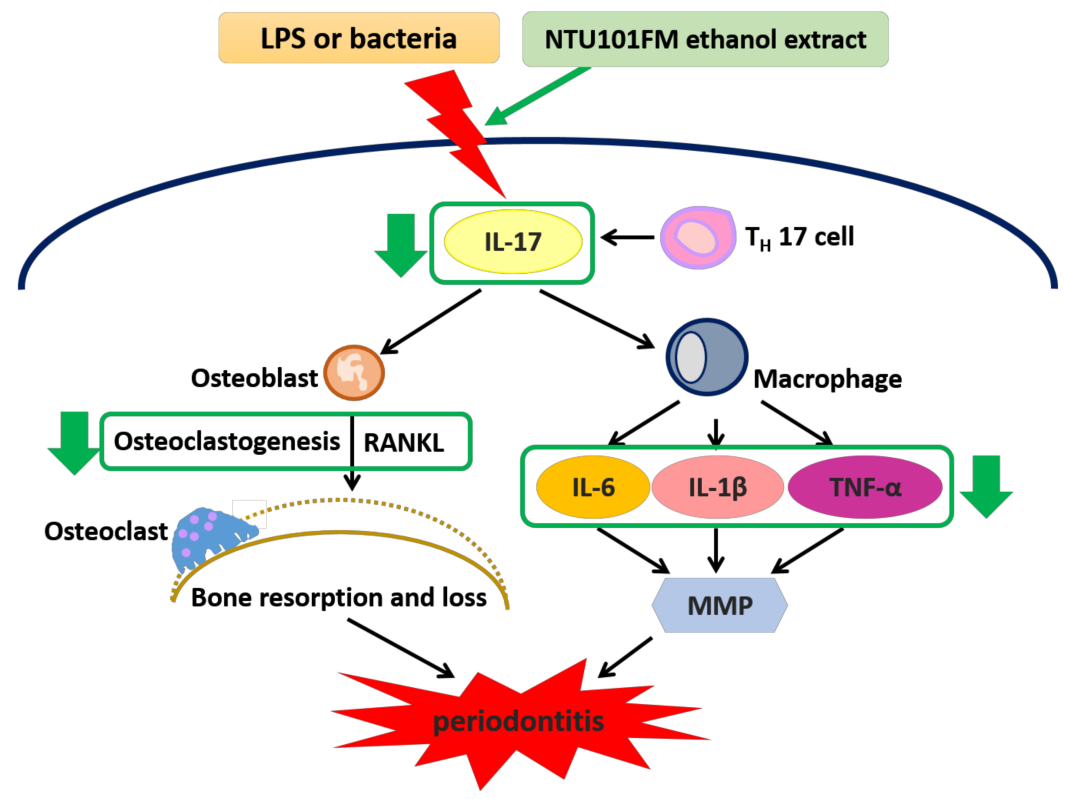

Figure 5. The proposed mechanism of NTU101FM ethanol extract to attenuate periodontal disease and its associated symptoms. LPS, lipopolysaccharide; IL-17, interleukin 17; $\mathrm{T}_{\mathrm{H}} 17$ cell, $\mathrm{T}$ helper type 17 cell; RANKL, receptor activator of nuclear factor kappa-B ligand; IL-6, interleukin 6; IL-8, interleukin 8; MMP, matrix metallopeptidase; IL-1 $\beta$, interleukin $1 \beta$; TNF- $\alpha$, tumor necrosis factor- $\alpha$.

Acknowledgments: This research did not receive any specific grant from funding agencies in the public, commercial, or not-for-profit sectors.

Author Contributions: T.-M.P. and T.-Y.T. conceived and designed the experiments. T.-H.L. performed the experiments. T.-H.L., T.-M.P. and T.-Y.T. analyzed the data and interpreted the results. T.-M.P. contributed the experimental reagents and materials. T.-H.L. wrote the paper.

Conflicts of Interest: The authors declare no conflict of interest.

\section{Abbreviations}

ABL

alveolar bone loss

ALP

alkaline phosphatase

DMEM

Dulbecco's modified Eagle's medium

DMSO

dimethyl sulfoxide

DPPH

2,2-diphenyl-1-picrylhydrazyl

ELISA

enzyme-linked immunosorbent assay

FBS

fetal bovine serum

IL

interleukin

LAB

lactic acid bacteria

LPS

lipopolysaccharide

MBCs

minimum bactericidal concentrations

MICs

minimum inhibitory concentrations

MTT

3-(4,5-dimethylthiazol)-2-yl-2,5-diphenyltetrazolium bromide

NO

nitric oxide 


$\begin{array}{ll}\text { NTU 101 } & \text { Lactobacillus paracasei subsp. paracasei NTU } 101 \\ \text { NTU101FM } & \text { NTU 101-fermented skim milk } \\ \text { PBS } & \text { phosphate-buffered saline } \\ \text { RANKL } & \text { receptor activator of nuclear factor-kB ligand } \\ \text { ROS } & \text { reactive oxygen species } \\ \text { TCA } & \text { trichloroacetic acid } \\ \text { TNF } & \text { tumor necrosis factor } \\ \text { TRAP } & \text { tartrate-resistant acid phosphatase }\end{array}$

\section{References}

1. Lindhe, J.; Ranney, R.; Lamster, I.; Charles, A.; Chung, C.P.; Flemmig, T.; Kinane, D.; Listgarten, M.; Löe, H.; Schoor, R.; et al. Consensus report: Chronic periodontitis. Ann. Periodontol. 1999, 4, 38. [CrossRef]

2. Wiebe, C.B.; Putnins, E.E. The periodontal disease classification system of the American academy of periodontology-An update. J. Can. Dent. Assoc. 2000, 66, 594-597. [PubMed]

3. Golpasand Hagh, L.; Zakavi, F.; Hajizadeh, F.; Saleki, M. The association between hyperlipidemia and periodontal infection. Iran. Red Crescent Med. J. 2014, 16, e6577. [CrossRef] [PubMed]

4. Tang, H.; Mattheos, N.; Yao, Y.; Jia, Y.; Ma, L.; Gong, P. In vivo osteoprotegerin gene therapy preventing bone loss induced by periodontitis. J. Periodontal. Res. 2015, 50, 434-443. [CrossRef] [PubMed]

5. Kobayashi, R.; Kobayashi, T.; Sakai, F.; Hosoya, T.; Yamamoto, M.; Kurita-Ochiai, T. Oral administration of Lactobacillus gasseri SBT2055 is effective in preventing Porphyromonas gingivalis-accelerated periodontal disease. Sci. Rep. 2017, 7, 545. [CrossRef] [PubMed]

6. Henderson, B.; Ward, J.M.; Ready, D. Aggregatibacter (Actinobacillus) actinomycetemcomitans: A triple A* periodontopathogen? Periodontology 2000 2010, 54, 78-105. [CrossRef] [PubMed]

7. Moradi, J.; Abbasipour, F.; Zaringhalam, J.; Maleki, B.; Ziaee, N.; Khodadoustan, A.; Janahmadi, M. Anethole, a medicinal plant compound, decreases the production of pro-inflammatory TNF-alpha and IL-1beta in a rat model of LPS-induced periodontitis. Iran. J. Pharm. Res. 2014, 13, 1319-1325. [CrossRef] [PubMed]

8. Lee, B.A.; Lee, H.S.; Jung, Y.S.; Kim, S.W.; Lee, Y.W.; Chang, S.H.; Chung, H.J.; Kim, O.S.; Kim, Y.J. The effects of a novel botanical agent on lipopolysaccharide-induced alveolar bone loss in rats. J. Periodontol. 2013, 84, 1221-1229. [CrossRef] [PubMed]

9. Chapple, I.L.; Matthews, J.B. The role of reactive oxygen and antioxidant species in periodontal tissue destruction. Periodontology 2000 2007, 43, 160-232. [CrossRef] [PubMed]

10. Villa-Correa, Y.A.; Isaza-Guzman, D.M.; Tobon-Arroyave, S.I. Prognostic value of 8-hydroxy-2'-deoxyguanosine and human neutrophil elastase/alpha1-proteinase inhibitor complex as salivary biomarkers of oxidative stress in chronic periodontitis. J. Periodontol. 2015, 86, 1260-1267. [CrossRef] [PubMed]

11. Kim, J.H.; Lee, D.E.; Cha, J.H.; Bak, E.J.; Yoo, Y.J. Receptor activator of nuclear factor- $\kappa B$ ligand and sclerostin expression in osteocytes of alveolar bone in rats with ligature-induced periodontitis. J. Periodontol. 2014, 85, 370-378. [CrossRef] [PubMed]

12. Bizzini, B.; Pizzo, G.; Scapagnini, G.; Nuzzo, D.; Vasto, S. Probiotics and oral health. Curr. Pharm. Des. 2012, 18, 5522-5531. [CrossRef] [PubMed]

13. Teanpaisan, R.; Dahlen, G. Use of polymerase chain reaction techniques and sodium dodecyl sulfate-polyacrylamide gel electrophoresis for differentiation of oral Lactobacillus species. Oral Microbiol. Immunol. 2006, 21, 79-83. [CrossRef] [PubMed]

14. Sookkhee, S.; Chulasiri, M.; Prachyabrued, W. Lactic acid bacteria from healthy oral cavity of Thai volunteers: Inhibition of oral pathogens. J. Appl. Microbiol. 2001, 90, 172-179. [CrossRef] [PubMed]

15. Krasse, P.; Carlsson, B.; Dahl, C.; Paulsson, A.; Nilsson, A.; Sinkiewicz, G. Decreased gum bleeding and reduced gingivitis by the probiotic Lactobacillus reuteri. Swed. Dent. J. 2006, 30, 55-60. [PubMed]

16. Saha, S.; Tomaro-Duchesneau, C.; Tabrizian, M.; Prakash, S. Probiotics as oral health biotherapeutics. Expert Opin. Biol. Ther. 2012, 12, 1207-1220. [CrossRef] [PubMed]

17. Zhao, J.J.; Feng, X.P.; Zhang, X.L.; Le, K.Y. Effect of Porphyromonas gingivalis and Lactobacillus acidophilus on secretion of IL1 $\beta$, IL6, and IL8 by gingival epithelial cells. Inflammation 2012, 35, 1330-1337. [CrossRef] [PubMed] 
18. Lin, F.M.; Chiu, C.H.; Pan, T.M. Fermentation of a milk-soymilk and Lycium chinense miller mixture using a new isolate of Lactobacillus paracasei subsp. paracasei NTU 101 and Bifidobacterium longum. J. Ind. Microbiol. Biotechnol. 2004, 31, 559-564. [CrossRef] [PubMed]

19. Liu, C.F.; Pan, T.M. In vitro effects of lactic acid bacteria on cancer cell viability and antioxidant activity. J. Food Drug Anal. 2010, 18, 77-86.

20. Chiang, S.S.; Pan, T.M. Beneficial effects of Lactobacillus paracasei subsp. paracasei NTU 101 and its fermented products. Appl. Microbiol. Biotechnol. 2012, 93, 903-916. [CrossRef] [PubMed]

21. Tsai, Y.T.; Cheng, P.C.; Pan, T.M. The immunomodulatory effects of lactic acid bacteria for improving immune functions and benefits. Appl. Microbiol. Biotechnol. 2012, 96, 853-862. [CrossRef] [PubMed]

22. Lin, T.H.; Pan, T.M. Inhibitory effect of Lactobacillus paracasei subsp. paracasei NTU 101 on rat dental caries. J. Funct. Foods 2014, 10, 223-231. [CrossRef]

23. Lin, T.H.; Lin, C.H.; Pan, T.M. The implication of probiotics in the prevention of dental caries. Appl. Microbiol. Biotechnol. 2018, 102, 577-586. [CrossRef] [PubMed]

24. Chua, M.T.; Tung, Y.T.; Chang, S.T. Antioxidant activities of ethanolic extracts from the twigs of Cinnamomum osmophloeum. Bioresour. Technol. 2008, 99, 1918-1925. [CrossRef] [PubMed]

25. Yen, G.C.; Duh, P.D. Scavenging effect of methanolic extracts of peanut hulls on free-radical and active-oxygen species. J. Agric. Food Chem. 1994, 42, 629-632. [CrossRef]

26. Erdogan-Orhan, I.; Sever-Yilmaz, B.; Altun, M.L.; Saltan, G. Radical quenching activity, ferric-reducing antioxidant power, and ferrous ion-chelating capacity of 16 Ballota species and their total phenol and flavonoid contents. J. Med. Food 2010, 13, 1537-1543. [CrossRef] [PubMed]

27. Schillinger, U.; Lücke, F.K. Antibacterial activity of Lactobacillus sake isolated from meat. Appl. Environ. Microbiol. 1989, 55, 1901-1906. [PubMed]

28. Kapadia, S.P.; Pudakalkatti, P.S.; Shivanaikar, S. Detection of antimicrobial activity of banana peel (Musa paradisiaca L.) on Porphyromonas gingivalis and Aggregatibacter actinomycetemcomitans: An in vitro study. Contemp. Clin. Dent. 2015, 6, 496-499. [CrossRef] [PubMed]

29. Chandrasekaran, M.; Venkatesalu, V. Antibacterial and antifungal activity of Syzygium jambolanum seeds. J. Ethnopharmacol. 2004, 91, 105-108. [CrossRef] [PubMed]

30. Studer, R.K.; Decker, K.; Melhem, S.; Georgescu, H. Nitric oxide inhibition of IGF-1 stimulated proteoglycan synthesis: Role of cGMP. J. Orthop. Res. 2003, 21, 914-921. [CrossRef]

31. Schneider, C.A.; Rasband, W.S.; Eliceiri, K.W. NIH Image to ImageJ: 25 years of image analysis. Nat. Methods 2012, 9, 671-675. [CrossRef] [PubMed]

32. Hatipoglu, H.; Yaylak, F.; Gungor, Y. A brief review on the periodontal health in metabolic syndrome patients. Diabetes Metab. Syndr. 2015, 9, 124-126. [CrossRef] [PubMed]

33. Lai, H.; Lo, M.T.; Wang, P.E.; Wang, T.T.; Chen, T.H.; Wu, G.H. A community-based epidemiological study of periodontal disease in Keelung, Taiwan: A model from Keelung community-based integrated screening programme (KCIS No. 18). J. Clin. Periodontol. 2007, 34, 851-859. [CrossRef] [PubMed]

34. Huttunen, E.; Noro, K.; Yang, Z. Purification and identification of antimicrobial substances produced by two Lactobacillus casei strains. Int. Dairy J. 1995, 5, 503-513. [CrossRef]

35. Pangsomboon, K.; Kaewnopparat, S.; Pitakpornpreecha, T.; Srichana, T. Antibacterial activity of a bacteriocin from Lactobacillus paracasei HL32 against Porphyromonas gingivalis. Arch. Oral Biol. 2006, 51, 784-793. [CrossRef] [PubMed]

36. Goldin, B.R. Health benefits of probiotics. Br. J. Nutr. 1998, 80, 203-207.

37. Cotter, P.D.; Hill, C.; Ross, R.P. Bacteriocins: Developing innate immunity for food. Nat. Rev. Microbiol. 2005, 3, 777-788. [CrossRef] [PubMed]

38. MacMicking, J.; Xie, Q.W.; Nathan, C. Nitric oxide and macrophage function. Annu. Rev. Immunol. 1997, 15, 323-350. [CrossRef] [PubMed]

39. Moncada, S. Nitric oxide: Discovery and impact on clinical medicine. J. R. Soc. Med. 1999, 92, $164-169$. [CrossRef] [PubMed]

40. Lu, S.H.; Huang, R.Y.; Chou, T.C. Magnolol ameliorates ligature-induced periodontitis in rats and osteoclastogenesis: In vivo and in vitro study. Evid. Based Complement. Altern. Med. 2013, 2013, 634095. [CrossRef] [PubMed] 
41. Song, F.; Wei, C.; Zhou, L.; Qin, A.; Yang, M.; Tickner, J.; Huang, Y.; Zhao, J.; Xu, J. Luteoloside prevents lipopolysaccharide-induced osteolysis and suppresses RANKL-induced osteoclastogenesis through attenuating RANKL signaling cascades. J. Cell. Physiol. 2018, 233, 1723-1735. [CrossRef] [PubMed]

42. Chen, X.; Zhi, X.; Pan, P.; Cui, J.; Cao, L.; Weng, W.; Zhou, Q.; Wang, L.; Zhai, X.; Zhao, Q.; et al. Matrine prevents bone loss in ovariectomized mice by inhibiting RANKL-induced osteoclastogenesis. FASEB J. 2017, 31, 4855-4865. [CrossRef] [PubMed]

43. Cho, K.A.; Park, M.; Kim, Y.H.; Ryu, K.H.; Woo, S.Y. Mesenchymal stem cells inhibit RANKL-RANKL interactions between osteoclasts and TH17 cells via osteoprotegerin activity. Oncotarget 2017, 8, 83419-83431. [CrossRef] [PubMed]

44. Ciucci, T.; Ibáñez, L.; Boucoiran, A.; Birgy-Barelli, E.; Pène, J.; Abou-Ezzi, G.; Arab, N.; Rouleau, M.; Hébuterne, X.; Yssel, H.; et al. Bone marrow TH17 TNF $\alpha$ cells induce osteoclast differentiation, and link bone destruction to IBD. Gut 2015, 64, 1072-1081. [CrossRef] [PubMed]

(C) 2018 by the authors. Licensee MDPI, Basel, Switzerland. This article is an open access article distributed under the terms and conditions of the Creative Commons Attribution (CC BY) license (http:/ / creativecommons.org/licenses/by/4.0/). 